Images in...

\title{
Rheumatic chorea: a video demonstration
}

\author{
Niyad U Pareeth,' Shaifali Bansal, ${ }^{2}$ Rakesh Biswas \\ ${ }^{1}$ Department of Critical Care, People's College of Medical Science, Bhopal, Madhya Pradesh, India \\ ${ }^{2}$ Medicine Department, People's College of Medical Sciences and Research Centre, Bhopal, Madhya Pradesh, India
}

Correspondence to Rakesh Biswas, rakesh7biswas@gmail.com

\section{DESCRIPTION}

A 10-year-old boy presented to us with a history of sudden onset of abnormal movements from the last 8 days. On examination, he had no problems except some abnormal movements of the lips, hands and feet (see video 1 ).

Video 1 Abnormal movements in a young boy. 10.1136/ bcr.08.2010.3257v1

\section{DISCUSSION}

This patient had no family history of movement disorder. He never had seizures or intellectual impairment. His blood examination showed normal complete blood count and erythrocyte sedimentation rate along with a normal antistreptolysin $\bigcirc$ titre.

Movement disorder in this 10-year-old boy (video 1) is characterised by rapid uncoordinated, jerking movements mainly in face, hands and feet, which is also quasipurposive as you can see him trying to hide the problem by putting his right hand into his pockets.

We sent this video to a US-based neurolistserv frequented by neurologists globally for an opinion and the responses are as below.

\section{Message from: Hussein $\mathbf{H}$ Abdel-Dayem}

These involuntary movements appear to be of chorea (mainly proximal, non-repetitive, non-purposeless and rapid).

Dr Hussein Abdel-Dayem, MD, Professor of Child Neurology, Faculty of Medicine, Alex University, Egypt.

\section{Message from: Jorge A Romero}

He has chorea, and some mild dystonic features.

You did not give much clinical information. Is there a family history of movement disorder? Are there seizures? Intellectual impairment? Any other symptoms that preceded the onset of the neurologic signs?
In a 10-year-old with new onset of this movement disorder, I would be concerned about Sydenham's chorea, particularly with the relatively rapid onset.

Jorge A Romero, MD, Baylor University Medical Center, 3600 Gaston Avenue Suite 901, Dallas, Texas 75246, USA.

In rheumatic chorea or Sydenham's chorea (SC), the abnormal movements may merge imperceptibly into purposeful or semi-purposeful acts, sometimes making the chorea hard to identify.

Chorea may also be seen with Huntington's disease and as a complication of medication (levodopa, anticonvulsants, antipsychotics). Our patient did not have a history of medication intake before his symptoms started. He was unlikely to be affected by Huntington's disease because of the absence of the same in the family history and it did not occur in adulthood as is usually the case.

The patient was also suspected of SC due to the commonality of this particular aetiology in our part of the world. ${ }^{1}$ SC usually develops in those aged $3-13$ years and is believed to result from a preceding streptococcal infection. The patient may have no history of rheumatic fever and a preceding streptococcal infection cannot always be documented. Infections can be subclinical and often precede the development of neurologic symptoms by age 1-6 months. At least $25 \%$ of patients with SC fail to have serologic evidence of prior infection. ${ }^{2}$

Acknowledgements To all those who cared for this patient.

Competing interests None.

Patient consent Obtained.

\section{REFERENCES}

1. Kulkarni ML, Anees S. Sydenham's chorea. Indian Pediatr 1996;33:112-15.

2. Robertsen WC, Mohamed I. Chorea in Children, Emedicine. http:// emedicine.medscape.com/article/1181993-overview (accessed 7 June 2010). 


\section{BMJ Case Reports}

This pdf has been created automatically from the final edited text and images.

Copyright 2010 BMJ Publishing Group. All rights reserved. For permission to reuse any of this content visit http://group.bmj.com/group/rights-licensing/permissions. BMJ Case Report Fellows may re-use this article for personal use and teaching without any further permission.

Please cite this article as follows (you will need to access the article online to obtain the date of publication).

Pareeth NU, Bansal S, Biswas R. Rheumatic chorea: a video demonstration. BMJ Case Reports 2010;10.1136/bcr.08.2010.3257, date of publication

Become a Fellow of BMJ Case Reports today and you can:

- Submit as many cases as you like

- Enjoy fast sympathetic peer review and rapid publication of accepted articles

- Access all the published articles

- Re-use any of the published material for personal use and teaching without further permission

For information on Institutional Fellowships contact consortiasales@bmjgroup.com

Visit casereports.bmj.com for more articles like this and to become a Fellow 